\title{
POLA PEMBINAAN KEAGAMAAN PESERTA DIDIK MELALUI PROGRAM PALU KANA MAPANDE (PKM) DI KOTA PALU
}

\section{ANDI ANIRAH}

\begin{abstract}
Abstrad:
This study discusses the pattern of religious guidance of learners through PKM program, learning interests, and the implications of religious guidance through PKM program in Elementary School Inpres Perumnas Palu Barat. This research is a qualitative descriptive research based on phenomenological approach, that is describing various events and its relation to learners in certain situations. Data collection is done through observation, interview, and documentation. The results showed that the pattern of religious guidance through PKM program in SD N Gugus IV (SD Inpres Perumnas) was greeted enthusiastically by the students. However, the interest of learners in following religious coaching is different, some are very enthusiastic, but some of them not enthusiastic. The implication of religious guidance through PKM program can correct and improve the ability of learners in reading and writing verses of $\mathrm{Al}$ Quran. They can also actualize memorization materials, daily prayers, and understand the procedures of worship in daily life.
\end{abstract}

Keyuards Palu kana mapande, BTQ, pendidikan agama islam 


\section{Pendahuluan}

Pendidikan adalah suatu usaha sadar dan bertujuan untuk mengembangkan kualitas manusia. Sebagai suatu kegiatan yang sadar akan tujuan, maka pelaksanaannya berada dalam suatu proses yang berkesinambungan dalam setiap jenis dan jenjang pendidikan. ${ }^{1}$

D alam Undang-undang No. 20 Tahun 2003 tentang sistem pendidikan nasional pada bab II pasal 3 disebutkan bahwa pendidikan nasional berfungsi Mengembangkan kemampuan dan membentuk watak serta peradaban bangsa yang bermartabat dalam rangka mencerdaskan kehidupan bangsa, bertujuan untuk berkembangnya potensi peserta didik agar menjadi manusia yang beriman dan bertakwa kepada Tuhan Yang Maha Esa, berakhlak mulia, sehat, berilmu, cakap, kreatif, mandiri, dan menjadi warga negara yang demokratis serta bertanggungjawab. ${ }^{2}$

Pendidikan merupakan salah satu kebutuhan manusia dalam upaya mengembangkan potensi dirinya untuk memiliki kualifikasi kemampuan yang mencakup kecerdasan, pengetahuan, kepribadian, akhlak mulia, keterampilan, daya saing, semangat juang, dan kreatifitas inovatif untuk dapat hidup mandiri dan berdaya saing. Oleh karena itu, pemerintah provinsi dan pemerintah kabupaten/ kota wajib memberikan layanan pendidikan bagi warga negara Indonesia.

Tingkat satuan pendidikan yang dianggap sebagai dasar pendidikan adalah sekolah dasar (SD). Secara umum pengertian sekolah dasar dapat kita katakan sebagai institusi pendidikan yang menyelenggarakan proses pendidikan dasar dan mendasari proses pendidikan selanjutnya. Pendidikan ini diselenggarakan untuk anak-anak yang telah berusia tujuh tahun dengan asumsi bahwa anak seusia tersebut mempunyai tingkat pemahaman dan kebutuhan pendidikan yang sesuai dengan dirinya. Pendidikan dasar diselenggarakan untuk memberikan dasar pengetahuan, sikap

${ }^{1}$ Syaiful Bahri Djamarah, Guru dan Anak Didik dalam Interaksi Edukatif, ( Jakarta: PT. Rineka Cipta, 2005) h.22

${ }^{2}$ Departemen Pendidikan Nasional RI, Undang Undang Nomor 20 Tahun 2003 Tentang Sistem Pendidikan Nasional (Jakarta: Direktorat Jendral Pendidikan Dasar dan Menengah Departemen Pendidikan Nasional, 2003), h. 2. 
dan keterampilan bagi anak didik. Pendidikan dasar inilah yang selanjutnya dikembangkan untuk meningkatkan kualitas diri peserta didik.

Kementerian Pendidikan dan Kebudayaan Republik Indonesia adalah kementerian dalam Pemerintah Indonesia yang menyelenggarakan urusan di bidang pendidikan anak usia dini, pendidikan dasar, pendidikan menengah, dan pendidikan masyarakat, serta pengelolaan kebudayaan. Kementerian Pendidikan dan Kebudayaan berada di bawah dan bertanggung jawab kepada Presiden ${ }^{3}$.

Tahun ini pemerintah mengeluarkan kebijakan dengan menambah jam pelajaran agama di seluruh SD swasta maupun negeri yang ada di kota Palu Penambahan jam pelajaran agama itu dikenal dengan nama program 'Palu Kama Mapande atau 'Palu harus pintar'. Program PKM ini dilatar belakangi oleh keinginan pemerintah kota Palu untuk membangun generasi muda menjadi generasi yang berakhlaq mulia, mempunyai kepribadian yang baik.

Pembinaan karakter pada tingkat Sekolah Dasar (SD) diberikan kepada peserta didik melalui program Palu Kana Mapande yang merupakan terobosan pemerintah kota Palu melalui Dinas Pendidikan dan Kebudayaan. Program ini dimaksudkan agar terpenuhinya target pencapaian pembinaan kegamaan melalui belajar tambahan bagi peserta didik, khususnya pada kelas V di tingkat sekolah dasar di kota Palu.

Program tersebut bertujuan untuk membantu mengembangkan potensi peserta didik ke arah pembentukan sikap, pengetahuan, dan keterampilan keagamaan. Mempersiapkan anak agar mampu mengembangkan sikap, pengetahuan, dan keterampilan keagamaan yang telah dimilikinya melalui program pendidikan lanjutannya. Penambahan jam belajar agama tersebut untuk pembentukan moral dan karakter peserta didik, peningkatan pengetahuan tentang agama, serta melatih peserta didik mengenal, menulis dan membaca Alquran.

Penelitian ini bertujuan untuk mendeskripsikan secara mendalam tentang pola pembinaan keagamaan peserta didik melalui program PKM di SDN gugus IV Kecamatan Palu Barat. Spesifikasi penelitian ini bertujuan untuk : mengetahui pola

${ }^{3}$ Peraturan Presiden Nomor 14 Tahun 2015 tentang Kementerian Pendidikan dan Kebudayaan. 
pembinaan keagamaan peserta didik melalui program PKM di di SD Inpres Perumnas Kecamatan Palu Barat .mengetahui minat peserta didik dan implikasi pola pembinaan keagamaan peserta didik melalui program PKM di SD Inpres Perumnas Kecamatan Palu Barat .

\section{Pembahasan}

Pembinaan adalah usaha, tindakan dan kegiatan yang diadakan secara berdaya guna dan berhasil guna untuk memperoleh hasil yang lebih baik. ${ }^{4}$ Pembinaan juga dapat berarti suatu kegiatan yang mempertahankan dan menyempurnakan apa yang telah ada sesuai dengan yang diharapkan. ${ }^{5}$

Pembinaan adalah suatu usaha atau kegiatan yang dilakukan untuk meningkatkan apa yang sudah ada kepada yang lebih baik (sempurna) baik dengan melalui pemeliharaan dan bimbingan terhadap apa yang sudah ada (yang sudah dimiliki), serta mendapatkan hal yang belum dimilikinya yaitu pengetahuan dan kecakapan yang baru. Pembinaan keagamaan pada peserta didik sejalan dengan upaya pendidikan yang berbasis karakter. Pendidikan karakter sejak tahun 2010 telah didengungkan sebagai bangsa yang berkarakter, bermartabat dan disegani oleh dunia internasional.

D ari wacana itu semangat membentuk pribadi bangsa yang berkarakter. Nilai yang terdapat dalam pendidikan karakter adalah jujur, disiplin, toleransi, cinta tanah air. Hal ini relevan dengan nilai karakter dalam pendidikan agama. ${ }^{6}$

Pola pembinaan keagamaan atau pendidikan karakter harus dikembangkan di sekolah - sekolah, mulai dari sekolah dasar sampai perguruan tinggi. Sekolah dasar merupakan dasar pembinaan keagamaan atau kepribadian peserta didik. Menurut Saleh pendidikan karakter berkaitan dengan moral dalam proses pembentukannya atau perubahan akhlak pada diri siswa yang dapat

4 Departemen Pendidikan dan Kebudayaan, Kamus Besar Bahasa Indonesia, (Jakarta :Balai Pustaka, 1990), h. 37.

5 Hendyat Soetopo dan Wanty Soemanto, Pembinaan dan Pengembangan Kurikulum, (Jakarta : Bina Aksara, 1982), h. 43

${ }^{6}$ Muhammad Rohmadi, Pendidikan Agama : Pendidikan Karakter Berbasis Agama (Jakarta : Lingkar Media, 2010),h.52 
diaktualisasikan dengan menerapkan nilai-nilai kejujuran, kesopanan, keadilan, kedisiplinan, dan tanggung jawab. ${ }^{7}$

Pemahaman yang mendalam dari praktisi pendidikan terhadap konsep pendidikan karakter menjadi taruhan bagi keberhasilan pendidikan karakter di setiap satuan pendidikan. Meskipun pendidikan karakter di wilayah Kota Palu sudah mulai diintegrasikan dalam kurikulum dihampir semua jenjang pendidikan, $^{8}$

Pembinaan keagamaan diarahkan agar semakin tertata kehidupan beragama yang harmonis, semarak dan mendalam serta ditujukan pada peningkatan kualitas keimanan dan ketaqwaan terhadap Tuhan Yang Maha Esa. Terpeliharanya kemantapan kerukunan hidup umat beragama, bermasyarakat dan berkualitas dalam meningkatkan kesadaran dan peran serta akan tanggung jawab terhadap perkembangan akhlak serta secara bersama-sama memperkokoh kesadaran spiritual, moral dan etika bangsa dalam pelaksanaan pembangunan nasional, peningkatan pelayanan, sarana dan prasarana kehidupan beragama.

Hal ini dimaksudkan untuk lebih memperdalam pengalaman ajaran dan nilai-nilai agama untuk membentuk akhlak mulia, sehingga mampu menjawab tantangan masa depan. Peningkatan kualitas keimanan dan ketakwaan terhadap Tuhan Yang Maha Esa diarahkan melalui pemahaman dan pengamalan nilai-nilai spiritual, moral dan etik agama, sehingga terbentuk sikap batin dan sikap lahir yang setia. ${ }^{9}$

Pembinaan keagamaan juga merupakan pendidikan Islam yang sama membimbing, mendidik ke arah yang lebih baik. Dari pengertian pembinaan tersebut dapat disimpulkan bahwa tujuan pembinaan adalah agar tercapainya kesempurnaan, artinya untuk mengadakan peningkatan dari yang sebelumnya. Bila sebelumnya kurang baik dan tidak sesuai dengan yang diinginkan.

7 Muwafik Saleh, Membangun Karakter dengan Hati Nurani, Pendidikan Karakter untuk Generasi Bangsa, ( Jakarta : Erlangga, 2012), h.78

8 Zulnuraini: Pendidikan Karakter: Konsep, Implementasi dan Pengembangannya di Sekolah Dasar di Kota Palu. Jurnal DIKDAS, No.1, Vol.1, September 2012

9 Abdul Rahman Shaleh, Pendidikan Agama dan Keagamaan, Misi, Visi dan Aksi, (Jakarta : PT Gemawinda Panca Perkasa, 2000), h. 204 
Penanaman keyakinan terhadap Tuhan bisa dilakukan melalui proses pendidikan. Pendidikan Islam merupakan kebutuhan manusia, karena sebagai makhluk paedagogis, manusia dilahirkan membawa potensi dapat dididik dan mendidik hingga menjadi khalifah dibumi, serta pendukung dan pemegang kebudayaan. $^{10}$

Pembinaan agama ini ditujukan kepada anak yang nantinya akan berperan dalam pembinaan generasi muda pada umumnya dan kehidupan moral dan agama khususnya sangat penting. Karena nilai-nilai moral agama yang akan menjadi pengendali dan pengaruh dalam kehidupan manusia itu adalah nilai-nilai masuk dan terjalin ke dalam pribadinya. Pada kenyataan manusia membutuhkan bimbingan serta petunjuk atau hidayah ke jalan yang benar untuk kebahagiaan dunia dan akhirat. Sebab itulah Islam mengajarkan agar para pemeluknya selalu memperhatikan kehidupan dunia dan akhirat.

Pendidikan Agama Islam tidak akan bisa lepas dari pembelajaran Alqur'an. Seperti yang diterapkan sekolah-sekolah formal, untuk meningkatkan kemampuan anak dalam pembelajaran mengenai Alqur'an. Jadi, pembelajaran Alqur'an adalah suatu proses belajar, untuk mengetahui segala sesuatu tentang Alqur'an, dan diharapkan mampu merubah jiwa dan kepribadian yang sesuai dengan petunjuk Alqur'an.

\section{Kunikulum danMatei pembdajaran PAI Tingkat SD}

Kurikulum sekolah dasar merupakan seperangkat rencana dan pengaturan isi dan bahan pelajaran serta cara yang digunakan sebagai pedoman penyelenggaraan kegiatan belajar-mengajar di SD . Pengembangan kurikulum dilakukan dengan mengacu pada standar nasional pendidikan. Kurikulum pada semua jenjang dan jenis pendidikan dikembangkan dengan prinsip diversifikasi sesuai dengan satuan pendidikan, potensi daerah, dan peserta didik.

Pendidikan Agama Islam (PAI) sebagai bagian dari Kurikulum 2013 memiliki peran yang sangat penting berkenaan dengan pendidikan karakter sebagai tujuannya. Sebagai integrator maka Pendidikan Agama Islam (PAI) menghimpun kompetensi pengetahuan, sistem nilai dan kompetensi ketrampilan yang

10 Abdul Mujib \& Dian Andayani., Pendidikan Agama Islam Berbasis Kompetensi : Konsep dan Implementasi Kurikulum . (Bandung: PT Remaja Rosdakarya, 2006), h. 130. 
diaktualisasikan dalam sikap/ watak Islami. Sekalipun diterbitkan oleh Puskurbuk Kemdiknas, isi Kurikulum Pendidikan Agama Islam (PAI) 2013 dibuat oleh Kemenag RI berdasarkan Keputusan Menteri Agama no. 211 tahun 2011 tentang Pedoman Pengembangan Standar Nasional Pendidikan Agama Islam pada Sekolah. Pembelajaran agama Islam di sekolah dasar mengacu pada kurikulum 2013 yang terdiri dari berbagai kompetensi.

Kurikulum 2013 disusun untuk menyempurnakan kurikulum sebelumnya dengan pendekatan pembelajaran aktif berdasarkan nilai-nilai agama dan budaya bangsa. Berkaitan dengan hal ini, Pemerintah telah melakukan penyesuaian nama mata pelajaran Pendidikan Agama Islam menjadi Pendidikan Agama Islam dan Budi Pekerti.

Kurikulum 2013 telah menyusun kompetensi inti (KI) sebagai pengganti standar kompetensi. Kompetensi inti adalah tingkat kemampuan untuk mencapai standar kompetensi lulusan yang harus dimiliki seorang peserta didik pada setiap kelas atau program. ${ }^{11}$ Kompetensi Inti memuat kompetensi sikap spiritual, sikap sosial, pengetahuan, dan keterampilan yang dikembangkan ke dalam Kompetensi D asar (KD). Kompetensi D asar (KD) adalah tumpuan untuk mencapai kompetensi inti yang harus diperoleh peserta didik melalui pembelajaran. Perubahan perilaku dalam pengamalan ajaran agama dan budi pekerti menjadi perhatian utama.

Kurikulum 2013 yang dirancang untuk mengembangkan kompetensi yang utuh antara pengetahuan, keterampilan, dan sikap. Selain itu, peserta didik tidak hanya diharapkan bertambah pengetahuan dan wawasannya, tapi juga meningkat kecakapan dan keterampilannya serta semakin mulia karakter dan kepribadiannya atau yang berbudi pekerti luhur.

Penambahan jam pembelajaran PAI dan Budi Pekerti dimaksudkan untuk mengoptimalkan pengamalam agama Islam bagi peserta didik dan membentuk budaya Islami di sekolah. Oleh karena itu, penerapan metode pembiasaan dan keteladanan bagi peserta didik mutlak di perlukan.

Dasar dan Tujuan Penhinaan Keagamaan pada Pesata Didik

11 Peraturan Pemerintah Nomor 32 Tahun 2013 tentang Standar Nasional Pendidikan pasal 1, ayat 13. 
Memberi pembinaan agama Islam terhadap anak-anak sama dengan melakukan dakwah. Dakwah merupakan salah satu bagian dari usaha penyebaran ajaran Islam disamping amar mánuf dan mahi mungkar. Jadi pembinaan terhadap peserta didik terutama pembinaan keagamaan bukan semata-mata hanya tugas guru PAI dalam lembaga. Sebagaimana tertuang dalam Kemenag RI atau ulama melainkan juga sebagai tugas kewajiban umat Islam secara keseluruhan, bahkan menurut Syeh Mahmud Abduh hukumnya wajib ain, artinya seluruh umat Islam tanpa terkecuali wajib berdakwah. Pelaksanaan Pendidikan Agama Islam di Indonesia untuk sekolah umum mempunyai dasar- dasar yang cukup kuat. D asar tersebut dapat ditinjau dari segi yaitu: yuridis, religius, dan sosial psychologis.

\section{a. D asar Y uridis}

Dasar yuridis ialah dasar-dasar pelaksanaan pendidikan agama Islam yang bersumber dari peraturan perundang-undangan yang secara langsung ataupun secara tidak langsung dapat dijadikan pegangan dalam melaksanakan pendidikan agama di sekolahsekolah atau pun di lembaga-lembaga pendidikan formal di Indonesia. D asar ideal, yaitu dasar yang bersumber dari falsafah Negara Pancasila, dimana sila pertama adalah Ketuhanan Yang Maha Esa. Ini mengandung pengertian bahwa seluruh bangsa Indonesia harus percaya kepada Tuhan Yang Maha Esa, atau tegasnya harus beragama.

Di dalam ketetapan MPR Nomor II/ MPR/ 1978 tentang P.4 (Eka Prasetia Pancakarsa) disebutkan bahwa: D engan sila Ketuhanan Yang Maha Esa, bangsa Indonesia menyatakan kepercayaan dan ketakwaan terhadap Tuhan Yang Maha Esa dan oleh karenanya manusia Indonesia percaya dan takwa terhadap Tuhan Yang Maha Esa sesuai dengan agama dan kepercayaan masing-masing menurut dasar kemanusiaan yang adil dan beradab. Untuk merealisir hal tersebut, maka di perlukan adanya pendidikan agama kepada anak-anak karena tanpa adanya pendidikan agama, akan sulit terwujud sila pertama dari Pancasila tersebut.

b. D asar Religius.

dasar religius adalah dasar pelaksanaan pendidikan agama di SD yang bersumber dari ajaran agama, dalam hal ini ajaran agama Islam. Berkaitan dengan dasar agama dalam pelaksanaan pendidikan agama Islam, maka dasar pertama dan utama ialah 
Alquran yang tidak dapat diragukan lagi kebenarannya, karena di dalam Alquran sudah tercakup segala masalah hidup dan kehidupan manusia. D asar religious pembinaan keagamaan adalah terdapat dalam Alquran dan al-Hadits yang semua telah difirmankan oleh Allah swt dan telah disabdakan oleh Rasulullah SAW. sebagaimana tertulis di dalam surah Ali Imran : 104:

"Dan hendaklah ada di antara kamu seglongan umat yangmenyeu kepada kebajikan, menyunh kepada yang ma'nuf dan meneegah dari yangmmkar; merkalah orangfarangyangbenuntungy. ${ }^{12}$

D alam surat At Tahrim ayat 6:

"Hai orangorangyangboriman, peiharalah dirimu dan kduarcamu dari api neraka yang bahan bakamya adalah manusia dan batur penjaganya malaikat-malaikat yang kasar, keras, dan tidak mendurhakai Allah terhadap apa yang dperintahkan-Nya kepada merka dan selalu mengrjakan apa yangdpeintahkan".

D engan demikian dapat dikatakan bahwa ayat yang di sebutkan di atas, memberikan pengertian bahwa dalam ajaran agama Islam memang adalah perintah untuk melaksanakan pendidikan agama baik di lingkungan keluarga, sekolah ataupun masyarakat.

c. Dasar Sosial.

Dalam kehidupan sehari-hari membutuhkan kepada bimbingan dan petunjuk yang benar, yang bernilai mutlak untuk kebahagiaan hidup di dunia dan di alam sesudah mati. Suatu yang mutlak pula, yaitu Allah SWT. Tuhan seru sekalian alam. Untuk itulah yang bersifat pengasih dan penyayang memberikan suatu anugrah kepada manusia yang beragama.

Adapun tujuan pembinaan keagamaan ini tidak terlepas dari tujuan hidup manusia, yakni untuk mencapai kebahagiaan hidup di dunia dan akhirat. Sebagaimana firman Allah dalam surah Al-Q ashash : 77:

“D an carilah pada apa yang Telah dianugerahkan Allah kepadamu (kebahagiaan) negeri akhirat, dan janganlah kamu melupakan bahagianmu dari (kenikmatan) duniawi dan berbuat baiklah (kepada orang lain) sebagaimana Allah Telah berbuat baik, kepadamu, dan janganlah kamu berbuat kerusakan di (muka) bumi.

12 Departemen Agama RI, Al-Qur'an dan Terjemahnya, Cet.II; Surabaya: Karya Utama, 2005,h.79 
Sesungguhnya Allah tidak menyukai orang-orang yang berbuat kerusakan". ${ }^{13}$

Pendidikan sejatinya merupakan proses pembentukan moral masyarakat beradab, masyarakat yang tampil dengan wajah kemanusiaan dan pemanusiaan yang normal. Artinya, pendidikan yang dimaksudkan di sini lebih dari sekedar sekolah (eluration not onlyeducationas Sdhoding melainkan pendidikan sebagai jaring-jaring kemasyarakatan (educationas communityneworks). ${ }^{14}$

Pendidikan diharapkan bisa memberikan sebuah kontribusi positif dalam membentuk manusia yang memiliki keseimbangan antara kemampuan intelektual dan moralitas. Dengan mensejajarkan dua komponen ini pada posisi yang tepat, diharapkan bisa mengantarkan kita untuk menemukan jalan yang lurus, shirat al-mustaqim Jalan yang akan dapat membuka mata hati dan kesadaran kemanusiaan kita sebagai anak-anak bangsa. Sehingga krisis yang hampir saja menghempaskan kita ke jurang kebangkrutan dan kehancuran, dengan segera dapat dilalui dan cepat berlalu.

Dasarnya diadakan atau dibentuknya program BTQ ini bertujuan untuk :

a. Membantu peserta didik yang belum mengenal, membaca, dan menulis Alquran

b. Memperdalam dan meningkatkan pengetahuan peserta didik dalam keterampilan baca tulis Alquran.

c. Memberikan motivasi kepada peserta didik agar lebih bergairah membaca Alquran sebagai kitab suci yang menjadi tuntunan umat Islam

d. Sebagai sarana tolak ukur keberhasilan mata pelajaran Pendidikan Agama Islam disekolah-sekolah.

\section{Modd penbdajaran PenddkanAgama d Sekdah Dasar.}

Model pembelajaran dapat diartikan sebagai cara, contoh maupun pola, yang mempunyai tujuan meyajikan pesan kepada siswa yang harus diketahui, dimengerti, dan dipahami yaitu dengan cara membuat suatu pola atau contoh dengan bahan-bahan yang dipilih oleh para pendidik atau seorang guru sesuai dengan materi yang diberikan dan kondisi di dalam kelas. Suatu model akan

${ }^{13}$ Ibid, h.556

14 Sudarwan Danim,.Agenda Pembaharuan Sistem pendidikan, (Yogyakarta: Pusaka Pelajar, 2003) h. 63-64 
mempunyai ciri-ciri tertentu dilihat dari faktor-faktor yang melengkapinya. Model pembelajaran adalah seluruh rangkaian penyajian materi ajar yang meliputi segala aspek sebelum sedang dan sesudah pembelajaran yang dilakukan guru serta segala fasilitas yang terkait yang digunakan secara langsung atau tidak langsung dalam proses belajar mengajar. ${ }^{15}$

Pendapat yang lain model dapat diartikan sebagai suatu rencana atau pola yang digunakan dalam menyusun kurikulum, mengatur materi peserta didik, dan memberi petunjuk kepada pengajar di kelas dalam setting pengajaran atau setting lainnya. ${ }^{16}$ Kurikulum merupakan seperangkat rencana, dan pengaturan, serta cara yang digunakan sebagai pedoman penyelenggaraan kegiatan pembelajaran untuk mencapai pendidikan tertentu. ${ }^{17}$

Menurut Joyce dalam Trianto mengemukakan model pembelajaran adalah suatu perencanaan atau pola yang digunakan di kelas atau pembelajaran dalam tutorial dan untuk menentukan perangkat-perangkat pembelajaran ${ }^{18}$

Model Pembelajaran berfungsi sebagai pedoman bagi para pendidik dalam melaksanakan pembelajaran. Hal ini menunjukkan bahwa setiap model yang akan digunakan dalam pembelajaran menentukan perangkat yang dipakai dalam pembelajaran tersebut. ${ }^{19}$ Menurut Muhaimin bahwa model yang dipilih dan perlu dikembangkan dalam pembelajaran pendidikan agama Islam, yaitu model terhubung (connected) dan model sequenced ${ }^{20}$

\section{2, h. 58 \\ ${ }_{16}$ Jihad dan Harris. Evaluasi Pembelajaran.(Yogyakarta. Multi Presindo, 2012) \\ 17 Depdiknas, Undang-Undang Sistem Pendidikan Nasional, No. 20 tahun 2003. ( Bandung: Citra Umbara) h.7}

15 Istarani, Model Pembelajaran Innovatif. (Medan : Media Persada,

18 Trianto, Mendesain Model Pembelajaran Inovatif-Progressif: Konsep, Landasan, dan Implementasinya Pada Kurikulum Tingkat Satuan Pendidikan (Cet. 11; Jakarta: Prenada Media, 2009), h. 16.

19 Shoimin, Model Pembelajaran Innovatif dalam Kurikulum 2013.(Yogyakarta.Ar-Ruzz Media. 2014), h. 68

20 Muhaimin. Paradigma Pendidikan Islam, Upaya Mengefektifkan Pendidikan Agama di Sekolah. (Bandung : Remaja Rosdakarya, 20019), h. 79 
a. Model Terhubung (Connetee), yaitu model pembelajaran yang sengaja diusahakan untuk menghubungkan satu topik dengan topik lain dalam satu bidang studi.

b. Model Sequeneed yaitu model pembelajaran dimana pada saat guru PAI mengajarkan suatu aspek mata pelajaran PAI maka ia dapat menyusun kembali urutan topik suatu mata pelajaran tersebut dan dimasukkannya topik-topik dari aspek lainnya dalam mata pelajaran PAI kedalam urutan pengajarannya, tentunya dalam topik yang sama atau relevan.

\section{Palu Kana Mapande (Palu Harus Pintar)}

Perhatian untuk memberikan pembinaan keagamaan peserta didik melalui Program Palu Kana Mapande ini didasari atas pandangan bahwa agama memiliki peran yang sangat penting dalam kehidupan manusia. Dalam era yang penuh tantangan dewasa ini, agama sangat penting dihadirkan menjadi pemandu kehidupan. D engan internalisasi nilai-nilai agama sejak dini terhadap setiap generasi diharapkan meningkatkan potensi spiritual dan membentuk peserta didik yang beriman dan bertakwa kepada Tuhan Yang Maha Esa serta berakhlak mulia, berkarakter, berintegritas, beradat, dan berbudaya.

Oleh karena itu, Program Palu Kana Mapande ini sesungguhnya bagian komitmen pemerintah Kota Palu newujudkan Visinya untuk menjadikan Kota Palu sebagai "Kda jasa, betbudaya, dan beradat yang dilandas dengan iman takwa kepada AllahSut'.

Penambahan jam pelajaran agama ini dikhususkan pada siswa kelas V pada tingkat sekolah dasar. Pembinaan keagamaan ini dilakukan tiga kali seminggu. Program PKM menjadi fokus Kelas V, karena kelas V merupakan kelas yang akan naik ke kelas VI, sehingga mereka perlu dipersiapkan. Sebab, sertifikat pelajaran tambahan ini akan menjadi salah satu syarat untuk masuk Sekolah Menengah Pertama (SMP).

PKM adalah program itu telah masuk dalam daftar belanja anggaran dan kegiatan Disdik Palu tahun ini. Program Palu Kana Mapande yang merupakan salah satu program strategis Pemerintah Kota Palu D alam pelaksanaanya bertujuan untuk mendorong siswa khususnya di tingkat sekolah dasar agar mampu membaca dan menulis Alquran. Pelaksanaan program ini mengacu pada 
kurikulum BTQ yang merupakan pedoman dalam pelaksanaan program tersebut.

Pemerintah Kota Palu, memaksimalkan penyelenggaraan pendidikan keagamaan untuk semua agama di seluruh Sekolah D asar (SD) swasta dan negeri di delapan kecamatan di kota Palu. Wali Kota Palu membuat program dalam upaya maksimalisasi pendidikan keagamaan. Pemerintah telah menganggarkan Rp 3 miliar untuk impelementasi program tersebut di seluruh Sekolah D asar (SD) yang akan dilaksanakan dan dikontrol langsung Dinas Pendidikan dan Kebudayaan kota tersebut.

Penambahan jam belajar agama tersebut untuk pembentukan moral dan karakter peserta didik, peningkatan pengetahuan tentang agama, serta melatih peserta didik mengenal dan membaca Alquran. Pendidik yang mengajar yaitu bukan guru yang telah mengajar sejak pagi sampai siang, karena pemerintah telah merekrut guru baru untuk mengajar baca tulis Alquran, pendidikan akhlak, tentang shalat dan sebagainya.

Kepala Dinas Pendidikan Kota Palu menerima tenaga pengajar yang bertugas untuk memberikan tambahan belajar agama yang disebar ke seluruh SD di Kota Palu sebanyak 331 terdiri dari 296 orang untuk agama Islam, 30 agama Kristen Protestan, dua orang Katolik, dua orang Agama Hindu dan satu orang untuk Agama Budha. Semoga kinerja tenaga pengajar ini bisa memberikan yang terbaik untuk generasi anak bangsa kedepan dalam mewujudkan iman dan taqwa.

\section{Tujuan ProgamPalu Kana Mapande}

Program Palu kana Mapande (PKM) adalah program unggulan Wali Kota Palu bekerjama dengan Dinas Pendidikan Kota Palu melalui penambahan jam pelajaran Agama terhadap peserta didik tingkat Sekolah Dasar (SD) pada tahun 2017. Penambahan jam pelajaran itu sebagai bentuk implementasi visi Wali Kota Palu. Pendidikan keagamaan tingkat sekolah dasar melalui program Palu Kana Mapande (PKM) yang digagas oleh pemerintah bertujuan agar peserta didik SD bisa baca tulis Alquran untuk agama Islam. Sementara agama lain menyesuaikan sesuai ajaran agamanya.

Keberadaan kurikulum pada Program Palu Kana Mapande yang berbasis pada penambahan jam pembelajaran agama pada peserta didik Kelas V di tingkat sekolah dasar di kota Palu. 
Olehnya itu kurikulum sangat penting disusun untuk dijadikan panduan pembelajaran agar target pencapaian pembinaan keagamaan pada program ini dapat tercapai sebagaimana yang diharapkan. Pendidikan karakter di kota Palu sudah mulai diintegrasikan dalam kurikulum dihampir semua jenjang pendidikan. Adapun ruang lingkup materi pada kurikulum pada program PKM :

a. Pembelajaran baca-tulis al-Qur'an berdasarkan hukum-hukum tajwid yang benar,

b. Pembinaan dan pembiasaan praktik pengamalan ibadah dan syari'at Islam,

c. Pembinaan dan pembiasaan berperilaku adab dan akhlak Islami dalam kehidupan sehari-hari.

Kompetensi inti yang diharapkan dari program PKM adalah terpenuhinya target pencapaian pembinaan keagamaan melalui belajar tambahan agama bagi siswa kelas V Sekolah D asar (SD) yang berkarakter, berimtak, dan berakhlak mulia. Kompetensi dasarnya adalah membentuk peserta didik yang menjadikan al-Qur'an sebagai bacaan utama, menghayati, dan mengamalkan, serta menjadikannya pedoman sebagai pedoman dalam kehidupan individu, sosial, dan masyarakatnya secara beradab di atas landasan iman dan takwa kepada Allah Swt.

Penambahan jam belajar pendidikan agama pada peserta didik usia sekolah dasar khususnya kelas V melalui Program Palu Kana Mapande (PKM) bertujuan untuk :

1. Membina dan mengembangkan kemampuan peserta didik untuk dapat membaca-tulis al-Q ur'an secara baik dan benar;

2. Membantu mengembangkan potensi peserta didik ke arah pembentukan sikap, pengetahuan, dan keterampilan keagamaan, melalui pendekatan yang disesuaikan dengan lingkungan dan latar perkembangan peserta didik, berdasarkan tuntunan al-Qur'an dan Sunnah Rasul;

3. Mempersiapkan anak agar mampu mengembangkan sikap, pengetahuan, dan keterampilan keagamaan yang telah dimilikinya melalui program pendidikan lanjutannya. ${ }^{21}$

21 Arifuddin Arif. Grand Desain Kurikulum dan Tambahan Pembelajaran Agama Islam di Tingkat Sekolah Dasar pada Kelas V sekota Palu. Tt.p 2017. h. 3 


\section{Matei penbeajaran progamPalu Kama Mapande}

Capaian pembelajaran pada program palu kana Mapande adalah terpenuhinya target pencapaian pembinaan keagamaan melalui belajar tambahan agama bagi siswa kelas V Sekolah D asar (SD) yang berkarakter, berimtak, dan berakhlak mulia. Membentuk peserta didik yang menjadikan al-Qur'an sebagai bacaan utama, menghayati, dan mengamalkan, serta menjadikannya pedoman sebagai pedoman dalam kehidupan individu, sosial, dan masyarakatnya secara beradab di atas landasan iman dan takwa kepada Allah Swt.

D alam buku Rubaiyat memuat materi pembelajaran yang digunakan pada program Palu Kana Mapande (PKM) sebagai berikut :

1. Mengenal huruf Hijaiyyah

a. Huruf hijaiyah dalam urutan Baghdadiyah

b. Mengenal huruf hijaiyah urutan rubaiyat

c. Huruf Hijaiyah dalam Berbagai Posisi

d. Latihan Menyebut Huruf-Huruf Al-Q ur'an

2. Membaca Kata

a. Membaca kata bertanda vokal: ai-u

b. Membaca kata bertanda vokal: anin-un

c. Membaca mati dan bunyi diftong

d. Menggandakan bunyi huruf

e. Latihan membaca kata dari lafadz-lafadz Al-Qur'an

3. Membaca Kalimat

a. Membaca panjang dua vokal

b. Membaca kalimat-kalimat Al-Qur'an

c. Meniadakan bacaan huruf tertentu

d. Melebur Nun Mati dan Tanwin / anin-un

e. Latihan membaca kalimat-kalimat dalam Al-Q ur'an

4. Membaca Alquran

a. Membaca huruf-huruf terpisah di awal surat

b. Menghentikan bacaan Al-Q ur'an

c. Berhenti sejenak (Saktah)

d. Tanda-Tanda Bacaan Al-Qur'an 


\section{e. Latihan Membaca Al-Q ur'an ${ }^{22}$}

\section{Penutup}

Pola pembinaan keagamaan peserta didik melalui program PKM di SD N gugus IV (SD Inpres Perumnas) Kecamatan Palu Barat pada kelas $\mathrm{V}$ dibagi menjadi lima kelompok belajar. Penambahan jam pelajaran agama yang dimulai dari jam 13.00 sampai dengan jam 15.00, dilakasanakan pada hari Selasa , Rabu dan Kamis. Khusus untuk BTQ mengunakan metode Rubaiyat yang mempunyai pola yaitu pahami, tunjuk, baca, dengar, lihat, sebutkan, dan tuliskan, ulangi dan nyanyikan. Beberapa metode lain yang digunakan oleh guru BTQ adalah klasikal (membaca bersama-sama dengan batas baca yang sama), individual (membaca satu persatu kedepan dengan batas baca yang berbeda antara siswa yang satu dengan yanag lain), dill (latihan), metode pemberian tugas, imla' (dikte), qiróah (dilagukan), metode tanya jawab, menyambung huruf hijaiyah menjadi ayat yang benar. Selain materi BTQ peserta didik juga diberikan pelajaran agama yaitu tata cara shalat, hafan surah pendek mulai surah An-nas sampai pada surah At-takasur, hafalan doa - doa harian.

Minat peserta didik dalam mengikuti pembinaan keagamaan melalui program PKM di SD Inpres Perumnas adalah berbeda beda, ada yang sangat antusias, ada juga yang biasa biasa saja. Peserta didik yang sangat antusias terlihat aktif pada saat menerima materi pelajaran, ini terbukti dari hasil evaluasi didapatkan nilai sangat memuaskan, kemampuan membaca alquran sudah bagus karena peserta didik telah tamat belajar di Taman Pendidikan Alquran (TPA), baik yang dilaksanakan di rumah penduduk dan di masjid- masjid yang ada kelompok pengajian Alqur'an. Peserta didik yang kurang berminat, mereka jarang masuk kelas pada saat pembelajaran berlangsung disebabkan karena mereka belum bisa membaca Alquran, bahkan ada yang belum mengenal huruf hijaiyyah, sehingga mereka malu dengan temannya- temannya, peserta didik inilah yang mendapatkan nilai dengan kategori cukup.

22 Buku Rubaiyat : Bahan Ajar Baca Tulis Al-Qur'an Tingkat Sekolah Dasar (SD) Kota Palu 2017.ttp. 
D aftar Pustaka

Abdul Mujib \& Dian Andayani., Pendidikan Agama Idam Bedbasis Komptens : Konsep dan Implenetasi Kurikulum. (Bandung: PT Remaja Rosdakarya, 2006.

A bdul Rahman Shaleh, Pendidikan Agama dan Keagamaan, Misi, V isi danAksi, Jakarta : PT G emawinda Panca Perkasa, 2000.

Buku Rubaiyat : Bahan Ajar Baca Tulis Al-Quran Tingkat Sdkdah Dasar(SD ) Kota Palu 2017.ttp.

Departemen Agama RI, Al-Quran dan Tejemahnya, Cet.II; Surabaya: Karya Utama, 2005.

D epartemen Pendidikan dan Kebudayaan, Kams Besar Bahasa Indonesia, Jakarta :Balai Pustaka, 1990.

D epartemen Pendidikan Nasional RI, Undang Undang Nomor 20 Tahun 2003 Tentang Sistem Pendidkan Nasionl. Jakarta: Direktorat Jendral Pendidikan Dasar dan Menengah D epartemen Pendidikan Nasional, 2003.

D epdiknas, UndangUndang Sistem Penddikan Nasional , No. 20 tahun 2003. Bandung: Citra Umbara, 2013.

Hendyat Soetopo dan Wanty Soemanto, Penbinaan dan Pengembangan Kunikulum (Jakarta : Bina Aksara, 1982), h. 43

Istarani, Modd Penbdajaran Imnovatif (Medan : Media Persada, 2012.

Jihad dan Harris. Evaluas Penbdajaran(Y ogyakarta. Multi Presindo, 2012)

Muhaimin. Paradgra Pendidikan Isam Upeya Mengfiktiffkan PendidkanAgama di Sekdah Bandung: Remaja Rosdakarya, 20019.

Muhammad Rohmadi, Pendidikan Agama : Pendidkan Karakter BebasisA gama (Jakarta : Lingkar Media, 2010),h.52

Muwafik Saleh, Menbangun Karakter dengan Hati Nurani, Penddikan Karakter untkk Geneasi Bangaa, Jakarta : Erlangga, 2012. 
Peraturan Presiden Nomor 14 Tahun 2015 tentang Kementerian Pendidikan dan Kebudayaan, https:/ / id.wikipedia.org/ wiki/ Kementerian

Pendidikan_dan_Kebudayaan_Republik_Ind̄onesia

Shoimin, Modd Penbdajaran Inmoatif dalam Kunikulum 2013. Y ogyakarta.Ar-Ruzz Media. 2014.

Sudarwan D anim,.Agenda Penbahanuan Sistem penddikan, Yogyakarta: Pusaka Pelajar, 2003.

Syaiful Bahri Djamarah, Gunu dan Anak Didik dalam Interaksi Edikatif, Jakarta: PT. Rineka Cipta, 2005.

Trianto, Mendesain Mood Penbdajaran Inovatif-Progessif: Konsep, Landasan, dan Implemetasinya Pada Kunkulum Tingkat Satuan Pendidikan Cet. 11; Jakarta: Prenada Media, 2009.

Zulnuraini: Penddikan Karakter. Konsep, Implenetas dan Pengenbanganmya di Skkdah Dasar di Kota Palu Jurnal DIKDAS, No.1, Vol.1, September 2012 